\title{
INTEGRATED CONCEPT OF STRATEGIC MANAGEMENT AS A TOOL FOR EFFECTIVE TECHNOLOGY TRANSFER IN R\&D ORGANISATIONS
}

\author{
Marija Mosurović Ružičić ${ }^{1}$, Vladimir Obradović ${ }^{2}$, Marina Dobrota ${ }^{3}$ \\ ${ }^{1}$ Institute "Mihajlo Pupin", University of Belgrade, Serbia \\ ${ }^{2,3}$ Faculty of Organisational Sciences, University of Belgrade, Serbia
}

\begin{abstract}
The process of strategic management in R\&D organizations implies a broader context of observation, taking into account the impact of significant changes from the environment at national and international levels, as well as the specific characteristics of scientific research work. Efficient strategic management of R\&D organizations means the existence of an integrated strategic management concept, and it is closely linked to efficient technology transfer, which is empirically presented in this paper on the example of $R \& D$ organizations (research institutes and faculties) in Serbia. Presented empirical research shows that efficient technology transfer has the strongest influence on the efficiency of R\&D organizations, their results and collaboration potential. This paper aims to present an integrated concept of strategic management in R\&D organisations as a tool by which many $R \& D$ results can be brought to life. The paper highlights the need for an integrated concept of strategic management in an R\&D organisation with the aim to improve the technology transfer.
\end{abstract}

Key words: strategic management, R\&D organizations, technology transfer.

\section{INTRODUCTION}

Research and development (R\&D) activities are very important ventures, mainly performed by the: enterprises, higher education institutions, and research institutes. Research institutes in the narrow sense are recognizable, strategically oriented research organizations that perform key functions within European innovation systems. They generate almost half of public-funded $\mathrm{R} \& \mathrm{D}$ costs at European Union level (Arnold, Barker, \& Slipersæter, 2010). Research institutes that are publicly funded represent an important aspect of the national innovation system and an important tool for fostering innovation and the performance of national economies. Their importance is reflected in the activities of creation, discovery, use, and diffusion of knowledge and their activities and impacts vary depending on the structure and type. Some are oriented to "blue sky" research; while others are pursuing short term market-oriented projects (OECD, 2011).

Frascati Manuel (2015) presents the internationally recognised methodology for collecting and using R\&D statistics. It includes definitions of basic concepts, data collection guidelines, and classifications for compiling R\&D statistics. According to the Frascati Manual (2015), one of the five basic characteristics of $R \& D$ indicates that " $R \& D$ activities should lead to the transfer of new knowledge". Taking into account the basic purpose of research and development, to enhance the stock of existing knowledge, the research output cannot be tacit (i.e. it cannot exist only in the mind of the researcher), because there would be a risk that the results and knowledge could be lost. Knowledge coding and its dissemination are a part of common practice in universities and research institutes. In the business environment, results are protected by secrecy or other intellectual property rights, but there is an expectation that processes and results should be useful to other researchers in the organisation (OECD, 2015).

The intellectual capital becomes increasingly important for organizational and project development as well as for economic progress. Nowadays, intangible assets become an important factor in future development

Corresponding author. Email: marija.mosurovic@pupin.rs

ISSN 2560-4961 (online)

(C) 2019 IPMA Serbia

doi: 10.18485/epmj.2019.9.2.8 
(Milošević, Dobrota, \& Barjaktarević Rakočević, 2018). Scientific work carried out in research organizations aims to enhance the existing knowledge base, while development activities aim to direct research and development results according to market demands. In research organizations, besides of R\&D activities, there are often activities related to the dissemination of research and technology transfer results. In the transition countries, it has been observed that there was no correlation between market demands and R\&D work (Jafee, A, 1984; Mosurović Ružičić, Semenčenko, \& Kutlača, 2015; Radošević, 2018).

Understanding the essence of research and development activities enables the understanding of the concept of globalization of research and development, which is a basic characteristic of modern society. Globalization of R\&D within the Frascati Manual (2015) means "financing, performance, transfer, and use of R\&D".

The main objective of the strategic management in R\&D organizations is an effective and efficient management of the research and development process, which should lead to the improvement of utilization of the R\&D results. Current studies on technology transfer and international technology transfer have one comprehensive approach that includes researchers from a cross-section of disciplines including organizational management, political science, economics, sociology, anthropology, marketing, and recently the management of technology (Wahab, Che Rose, \& Osman, 2012).

Efficient strategic management of $R \& D$ organizations means the existence of an integrated strategic management concept, and it is closely linked to efficient technology transfer, which will be empirically presented in this paper on the example of $R \& D$ organisations (research institutes and faculties) in Serbia. Technology transfer is a complex theme covered by many studies.

Technology transfer means moving of research results: ,from an industrial R\&D laboratory to the production line, from a non-profit $R \& D$ centre to an entrepreneurial new product developer, from university research centres to commercialization and from federally funded research centres to other scientific users or to industry for commercialization and new product development" (Suter, \& Strauss, 2007).

\section{NEW TRENDS IN TECHNOLOGY TRANSFER MANAGEMENT IN R\&D ORGANISATIONS}

The main failure of the most models for strategic management in R\&D organisations is in the fact that neither the $R \& D$ process, neither the strategic management process was considered in a comprehensive, analytically acceptable framework. Usually, only some phases of these processes are described, which makes it impossible to see the importance of applying strategic management with all its components in research organizations, which further implies that strategic management in these organizations faces numerous methodological and organizational challenges.

A modern approach to the strategic management of scientific work indicates the need for separate consideration of $R \& D$ management, management of technology and technology management in the organisation (Chanaron, \& Grange, 2006; Dabić, 2002; Murayama, Nirei, \& Shimizu, 2015). Technology management can also be related to organisations that do not have the capacity for R\&D activities but have a clearly developed need for specific scientific research results as well as information where they can find them. In these circumstances, cooperation between all innovation stakeholders within the national innovation system, where scientific research organizations have an important role, becomes increasingly important.

Changes in the research sector, which influence the need for applying the integrated concept of strategic management in $R \& D$ organisations can be systematized as follows (Arnold et al., 2010):

- Convergence. An increasing number of new technologies are based on science, which has a significant impact on technological progress. It is noted that there was a deletion of the 
existence of a strict distinction between traditional scientific branches - myco-electronics, biotechnologies, etc. This is the way to the thematic specialization of the institutes.

- Strengthening of the connections between universities and research institutes by involving $\mathrm{PhD}$ students in research projects in the institutes. At the same time, universities will be able to generate knowledge according to market needs.

- Globalization is seen as the driver of change in many areas, but also in the field of $R \& D$ taking place within institutes. A growing number of researchers are collaborating with each other, putting science development at the forefront and deleting national boundaries.

- Commercialization and the long-term importance of the market. Almost all institutes engaged in $R \& D$ activities constantly strive to benefit from their scientific research work through concrete commercial use. Recently, institutes have achieved increasing market incomes (competing for public and private affairs), but the degree of this income also differs from the types of institutes

- Organization and scale. It is necessary to redefine or form new measuring scale for scientific $R \& D$ results of $R \& D$ organisations. The adequate scale is necessary in order to be able to participate in international project calls more successfully.

- Research institutions should have a measuring scale for their research. That way, they could more easily participate in the race for sources of international funding. Modern business conditions impose knowledge as a significant resource for competitive advantage formation, which is why recent organizational theories emphasize the concept of "organizational learning". Organizational learning represents the evolved ability of an organization to learn continuously and some organizational theorists even go so far as to think that it can be the sole source of competitive advantage (Robins, 2005). Organizational learning determines an organizational structure that has almost no vertical line of authority, which enables the mobilization and management of knowledge and the highest possible level of participation in solving innovative problems.

- Politics. Creating a single European Research Area and increasing participation in various European programs and initiatives.

These changes have led to a redefinition of research priorities that are slowly shifting from basic research to applied research and their commercial application. The R\&D management process is gaining an important place within the strategic management of the organization. There is a new tendency of scientific research work management, especially related to research and development, which leads to the emergence of a brand-new approach called technological management, especially regarding $\mathrm{R} \& \mathrm{D}$ institutes.

\section{MANAGING THE TECHNOLOGY TRANSFER IN SERBIAN R\&D ORGANISATION}

The process of strategic management in $R \& D$ organizations implies a broader context of observation, taking into account the impact of significant changes from the environment at national and international levels, as well as the specific characteristics of scientific research work. Bearing in mind the main characteristics of strategic management, on the one hand, and bearing in mind the basic characteristics of the scientific research process, on the other, there was a need to develop a comprehensive framework that would integrate all these characteristics into synchronized, unified whole, applicable in scientific research organizations.

From the second half of the last century, the scientific-research system in Serbia is in the process of transformation from a planning system to a market-driven system. Development of an integrated strategic management concept that would be applicable to research organizations in Serbia should lead 
to an effective restructuring of these organizations.

\subsection{Challenges}

The economic transition from socialism to capitalism brought a lot of changes regarding technological competence, technological transfers, and research activities for the transition countries, after the 1990s (Svarc, \& Dabic, 2019). Like the most post-communist countries, Serbia faces the major challenges during the transition process (Racine, Goldberg, Goddard, Kuriakose, \& Kapil, 2009):

- Limited experience regarding the practical application of the research results. Scientific research organizations are generally more oriented on scientific work in terms of increasing the knowledge base, not on their practical application. There is a need for establishing international cooperation regarding the basic research in order to overcome the lack of financial resources and obsolete research infrastructure at the national level. But, a large number of national research organizations are not internationally competent;

- Lack of experience to understand market needs. For a long period of time, the R\&D activities were mostly supported by the government regardless of the market needs. It led to the insufficient or almost non-existent link between the research sector and industry;

- The age structure of management. Managers of research organizations are not sufficiently trained in strategic management of the organization. Managers are not motivated enough to create changes. They are able to observe how the organization, both financially and in terms of staff, is going down with no intention of doing anything because they believe that the degradation process will take long enough until their retirement;

- Members of the board of directors. The board of directors of research institutes often includes members who are elected for political reasons that support organizational restructuring but on a general basis. There is a lack of the industry representatives that could make a concrete contribution to the restructuring process;

- A large number of ",non-productive” staff. As a consequence of past human resources policy, there are still a lot of "non-research", administrative staff in research organisations;

- Brain drains. A lot of the researchers who have the capacity to trigger the change have left their organisations. They went either to foreign companies or abroad where they got better working conditions, both financially and intellectually. Most of those who are left are not interested in making any major change;

- Lack of transparency. In the past, a great deal of information on finances and other data has been designated as strictly confidential, so that the available figures of institutions are not sufficiently reliable and accurate;

Besides to the above-mentioned challenges, R\&D organizations in Serbia are also faced with:

- Constant lack of financial resources, especially from the industry, international funds, etc.

- Lack of research facilities and research infrastructure. As a result of the ownership transformation and lack of funding in a large number of research organisations, there were no long-term investments in $R \& D$ institutions in Serbia. There is obsolete equipment which does not allow conducting the cutting edge research. Research and development laboratories within major $R \& D$ institutions are within the process of structural transformation and shuttingdown.

The problem solutions can be sought in collaboration with other innovation stakeholders and the creation of appropriate infrastructural forms that can improve the quality of research outputs by diffusion and technology transfer. It is necessary to take comparative advantage based on quality, 
educated scientific staff and, with adequate knowledge management, to increase the participation of researchers within national and intentional projects' calls.

\subsection{Empirical research}

The empirical part of this work is based on research that covered employees from the accredited R\&D organisations in Serbia research institutes and faculties (Obradović, Mosurović Ružičić, \& Dobrota, 2019).

The integrated concept of strategic management in the scientific research organisations in Serbia was described with 14 consistent variables: external environment, internal environment, strategic documents, project portfolio, resources, organizational design, collaboration, monitoring, results, achievement assessment, system of lessons learnt, efficacy assessment, strategic management methods, and techniques and management capacity for managing innovation.

For the purposes of the research presented in this paper, we have developed the following research hypothesis:

The application of integrated strategic management concept in research and development organisations enables the efficient transfer of knowledge and technology from research organizations to the economy.

In order to test the starting hypothesis, the strategic management concept is presented with the set of components, which are systematized into consistent variables that express basic elements of the strategic management process in $\mathrm{R} \& \mathrm{D}$ organizations in Serbia.

Table 1 provides a descriptive summary of the variables that represent the core elements of the strategic integrated management concept. It gives an overview of each of the variables individually, number of its sub-elements, mean, standard deviation, minimum, maximum, results of Friedman's test (showing that the all sub-elements of the main variables differ among themselves), as well as Cronbach's Alpha, a measure of the validity of the scales by which variables are created. 
Table 1: Presentation of the basic elements of the integrated strategic management concept

\begin{tabular}{|c|c|c|c|c|c|c|c|c|}
\hline Variables & $\begin{array}{l}\text { No. } \\
\text { sub. } \\
\text { el. }\end{array}$ & Mean & SD & Min & Max & Friedman & $\begin{array}{l}\text { Fried } \\
\text { man } \\
\text { sig. }\end{array}$ & $\begin{array}{l}\text { Cronb } \\
\text { ach's } \\
\text { alpha }\end{array}$ \\
\hline $\begin{array}{l}\text { External } \\
\text { environment }\end{array}$ & 10 & 29.24 & 8.826 & 10 & 49 & $217.908 * * *$ & $<0.001$ & 0.891 \\
\hline $\begin{array}{l}\text { Internal } \\
\text { environment }\end{array}$ & 11 & 30.77 & 6.786 & 15 & 51 & $699.881 * * *$ & $<0.001$ & 0.782 \\
\hline $\begin{array}{l}\text { Strategic } \\
\text { documents }\end{array}$ & 4 & 11.62 & 5.008 & 4 & 20 & $109.032 * * *$ & $<0.001$ & 0.888 \\
\hline Project portfolio & 7 & 19.86 & 7.577 & 7 & 35 & $179.239 * * *$ & $<0.001$ & 0.901 \\
\hline Resources & 5 & 14.14 & 4.958 & 5 & 25 & $95.548 * * *$ & $<0.001$ & 0.803 \\
\hline $\begin{array}{l}\text { Organizational } \\
\text { design }\end{array}$ & 6 & 20.12 & 6.312 & 6 & 30 & $138.799 * * *$ & $<0.001$ & 0.885 \\
\hline Collaboration & 5 & 15.25 & 4.691 & 5 & 25 & $193.875^{* * *}$ & $<0.001$ & 0.795 \\
\hline Monitoring & 4 & 10.69 & 4.588 & 4 & 20 & $138.271 * * *$ & $<0.001$ & 0.878 \\
\hline Results & 7 & 23.40 & 7.050 & 10 & 35 & $253.243 * * *$ & $<0.001$ & 0.836 \\
\hline $\begin{array}{l}\text { Achievement } \\
\text { assessment }\end{array}$ & 6 & 16.28 & 6.651 & 6 & 30 & $245.375^{* * *} *$ & $<0.001$ & 0.902 \\
\hline $\begin{array}{l}\text { System of lessons } \\
\text { learnt }\end{array}$ & 4 & 9.65 & 4.726 & 4 & 20 & $68.104 * * *$ & $<0.001$ & 0.933 \\
\hline Ocena efikasnosti & 13 & 41.68 & $\begin{array}{l}14.54 \\
3\end{array}$ & 13 & 65 & $229.952 * * *$ & $<0.001$ & 0.963 \\
\hline $\begin{array}{l}\text { Methods and } \\
\text { techniques }\end{array}$ & 3 & 6.56 & 3.432 & 3 & 15 & $40.632 * *$ & $<0.001$ & 0.869 \\
\hline $\begin{array}{l}\text { Management } \\
\text { capacity for } \\
\text { managing } \\
\text { innovation }\end{array}$ & 7 & 20.762 & 5.707 & 7 & 35 & $250.44 * * *$ & $<0.001$ & 0.773 \\
\hline
\end{tabular}

Source: own research

For three variables, internal environment, collaboration, and management capacity for managing innovation, the value of Cronbach's Alpha is over 0.7 that indicate good internal consistency. Seven variables, external environment, strategic documents, resources, organizational design, monitoring, results, strategic management methods and techniques, have the Cronbach's Alpha value over 0.8 , which indicate very good internal consistency. The rest four variables project portfolio, achievement assessment, a system of lessons learnt, efficacy assessment have the
Cronbach's Alpha value over 0.9 which indicates excellent internal consistency.

It was further necessary to determine the difference between variables of the integrated strategic management concept by groups regarding the variable Technology transfer efficiency (Table 2). As all presented variables are not normally distributed, the KruskalWallis nonparametric test is used to determine whether there are statistically significant differences between groups.

Table 2: Differences of elements of integrated strategic management concept regarding the variable Technology transfer efficiency

\begin{tabular}{|cccccccc|}
\hline Variables & Groups & Mean & \pm & SD & Med. & K-W & $\begin{array}{c}\text { K-W } \\
\text { sig. }\end{array}$ \\
\hline \multirow{2}{*}{$\begin{array}{c}\text { External } \\
\text { environment }\end{array}$} & Low transfer & 27.16 & \pm & 8.207 & 27 & $7.178^{*}$ & 0.028 \\
\cline { 2 - 8 } & Average transfer & 30.00 & \pm & 8.415 & 29 & & \\
\cline { 2 - 8 } & High transfer & 30.39 & \pm & 8.797 & 32.5 & & \\
\hline \multirow{2}{*}{$\begin{array}{l}\text { Internal } \\
\text { environment }\end{array}$} & Low transfer & 29.53 & \pm & 7.26 & 30.5 & 4.841 & 0.089 \\
\cline { 2 - 8 } & Average transfer & 30.16 & \pm & 4.995 & 30 & & \\
\cline { 2 - 8 } & High transfer & 32.01 & \pm & 6.985 & 31.5 & & 0.191 \\
\hline
\end{tabular}




\begin{tabular}{|c|c|c|c|c|c|c|c|}
\hline \multirow{2}{*}{$\begin{array}{c}\text { Strategic } \\
\text { documents }\end{array}$} & Average transfer & 10.97 & \pm & 5.064 & 10 & & \\
\hline & High transfer & 12.22 & \pm & 5.040 & 12.5 & & \\
\hline \multirow[t]{3}{*}{ Project portfolio } & Low transfer & 18.10 & \pm & 7.120 & 18 & $11.378 * *$ & 0.003 \\
\hline & Average transfer & 19.58 & \pm & 8.404 & 18.5 & & \\
\hline & High transfer & 22.00 & \pm & 6.881 & 22 & & \\
\hline \multirow[t]{3}{*}{ Resources } & Low transfer & 13.22 & \pm & 5.019 & 13 & $7.601 *$ & 0.022 \\
\hline & Average transfer & 13.71 & \pm & 4.753 & 14 & & \\
\hline & High transfer & 15.38 & \pm & 4.469 & 15 & & \\
\hline \multirow{3}{*}{$\begin{array}{c}\text { Organizational } \\
\text { design }\end{array}$} & Low transfer & 18.69 & \pm & 6.589 & 19 & $10.212^{* *}$ & 0.006 \\
\hline & Average transfer & 19.26 & \pm & 6.583 & 19.5 & & \\
\hline & High transfer & 21.88 & \pm & 5.645 & 22 & & \\
\hline \multirow[t]{3}{*}{ Collaboration } & Low transfer & 13.5 & \pm & 4.644 & 13 & $22.023 * * *$ & $<0.001$ \\
\hline & Average transfer & 14.29 & \pm & 4.053 & 14 & & \\
\hline & High transfer & 17.03 & \pm & 4.350 & 17 & & \\
\hline \multirow[t]{3}{*}{ Monitoring } & Low transfer & 9.38 & \pm & 4.364 & 8 & $11.848 * *$ & 0.003 \\
\hline & Average transfer & 10.61 & \pm & 4.278 & 10 & & \\
\hline & High transfer & 11.88 & \pm & 4.474 & 12 & & \\
\hline \multirow[t]{3}{*}{ Results } & Low transfer & 16.84 & \pm & 4.127 & 17 & $115.547 * * *$ & $<0.001$ \\
\hline & Average transfer & 23.32 & \pm & 4.905 & 23.5 & & \\
\hline & High transfer & 29.40 & \pm & 4.665 & 30.5 & & \\
\hline \multirow{3}{*}{$\begin{array}{l}\text { Achievement } \\
\text { assessment }\end{array}$} & Low transfer & 15.19 & \pm & 6.43 & 15 & $10.392 * *$ & 0.006 \\
\hline & Average transfer & 15.34 & \pm & 6.727 & 14 & & \\
\hline & High transfer & 18.12 & \pm & 6.154 & 18 & & \\
\hline \multirow{3}{*}{$\begin{array}{c}\text { System of } \\
\text { lessons learnt }\end{array}$} & Low transfer & 8.62 & \pm & 4.452 & 7.5 & $8.642 *$ & 0.013 \\
\hline & Average transfer & 9.50 & \pm & 4.631 & 8 & & \\
\hline & High transfer & 10.79 & \pm & 4.660 & 12 & & \\
\hline \multirow{3}{*}{$\begin{array}{c}\text { Efficacy } \\
\text { assessment }\end{array}$} & Low transfer & 37.06 & \pm & 14.232 & 37.5 & $14.281 * * *$ & 0.001 \\
\hline & Average transfer & 41.42 & \pm & 15.137 & 41.5 & & \\
\hline & High transfer & 45.79 & \pm & 13.339 & 44.5 & & \\
\hline \multirow{3}{*}{$\begin{array}{l}\text { Methods and } \\
\text { techniques }\end{array}$} & Low transfer & 5.76 & \pm & 3.149 & 4 & $9.104 * *$ & 0.011 \\
\hline & Average transfer & 6.87 & \pm & 3.626 & 6 & & \\
\hline & High transfer & 7.21 & \pm & 3.299 & 7 & & \\
\hline
\end{tabular}

Table 2 shows the differences between the elements that represent the integrated strategic management concept regarding the variable Technology transfer efficiency. Based on Table 2, it can be seen that there is a difference regarding the technology transfer efficiency in terms of nearly all presented variables.

The most evident difference was observed for the Efficacy assessment (KW $=117.84, \mathrm{p}$ $<0.001)$. When comparing groups Inefficient transfer $(\mathrm{M}=27.12, \mathrm{SD}=10.845, \mathrm{Me}=26)$, Neutral efficiency transfer $(\mathrm{M}=40.33, \mathrm{SD}=$ $7.143, \mathrm{Me}=39)$, and Efficient transfer $(\mathrm{M}=$ $53.62, \mathrm{SD}=8.878, \mathrm{Me}=54)$, it is clear that the more efficient the technology transfer is, scientific research efficiency will be higher.

Another important difference was regarding the variable Results $(\mathrm{KW}=45.369, \mathrm{p}<0.001)$. With respect of the groups Inefficient transfer $(\mathrm{M}=18.82, \mathrm{SD}=5.798, \mathrm{Me}=18)$, Neutral transfer efficiency $(\mathrm{M}=23.11, \mathrm{SD}=6.55 . \mathrm{Me}$ $=22)$ and Efficient Transfer $(\mathrm{M}=26.68, \mathrm{SD}=$ $6.645, \mathrm{Me}=27$ ), the more efficient the technology transfer is, the organization's results will be better.

A significant difference was also seen regarding variable Collaboration $(\mathrm{KW}=$ $18.833, \mathrm{p}<0.001)$. When comparing groups Inefficient transfer $(\mathrm{M}=13.02, \mathrm{SD}=4.278, \mathrm{Me}$ =14), Neutral transfer efficiency $(M=15.35$, $\mathrm{SD}=3.671, \mathrm{Me}=15.5)$ and Efficient Transfer $(\mathrm{M}=16.49, \mathrm{SD}=5.005, \mathrm{Me}=16)$, the more efficient the technology transfer is, the cooperation in research and development activities will be better.

Figure 1, Figure 2 and Figure 3 represent the differences regarding the Technology transfer efficiency presented by boxplot diagram in terms of the variables Collaboration, Results, and Efficacy assessment. 


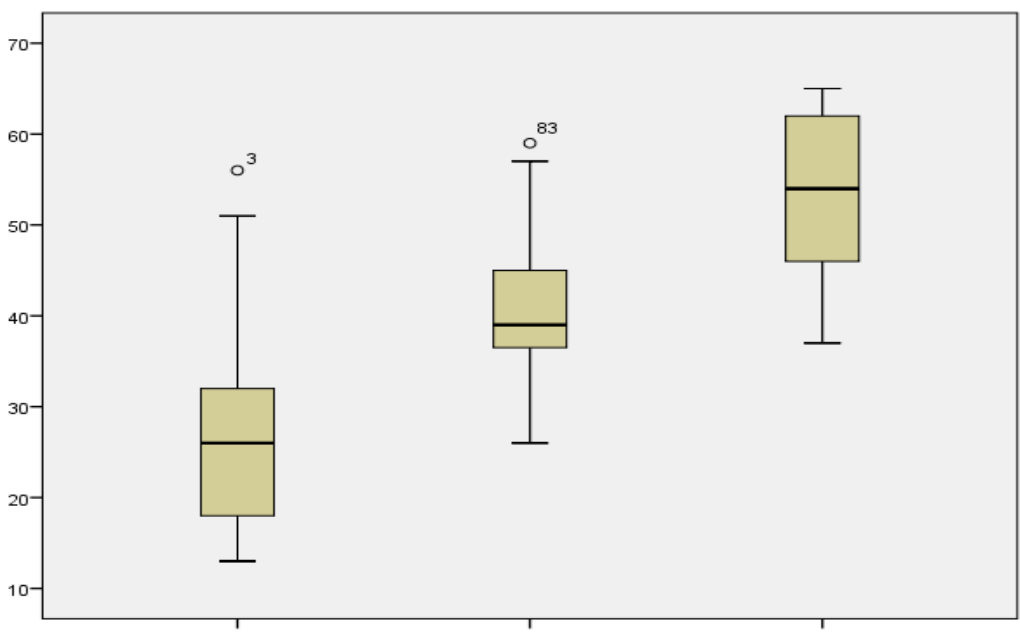

Figure 1: Boxplot diagram of the variable, Efficacy assessment versus Efficiency of technology transfer (1.Inefficient transfer, 2.Neutral transfer efficiency, 3.Efficient Transfer)

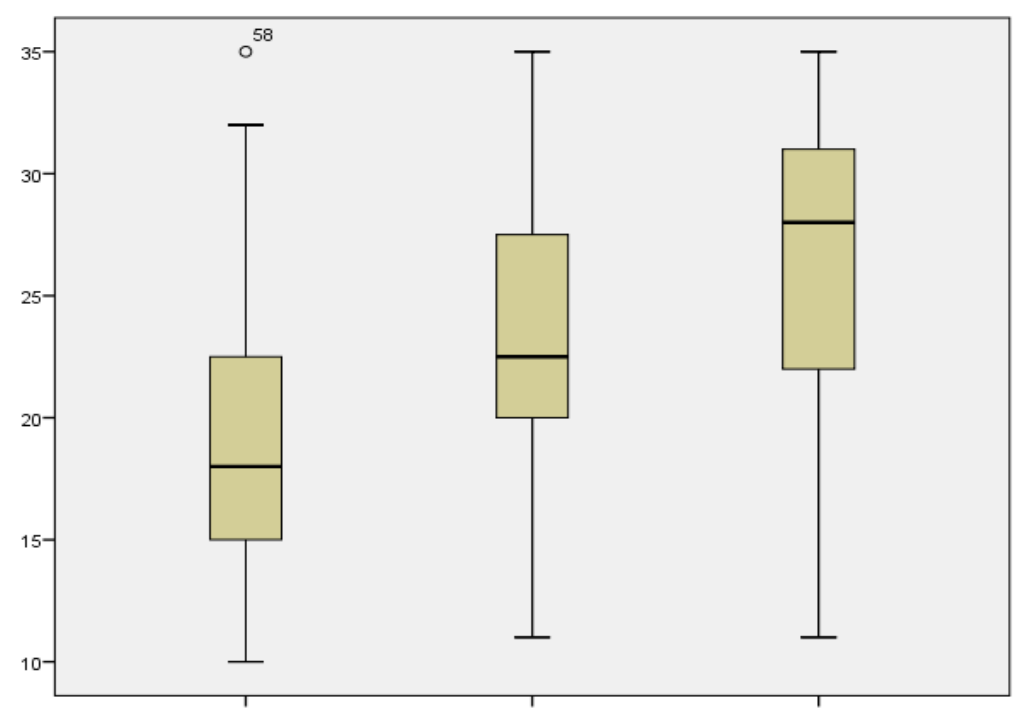

Figure 2: Boxplot diagram of the variable Results versus Efficiency of technology transfer (1.Inefficient transfer, 2.Neutral transfer efficiency, 3.Efficient Transfer) 


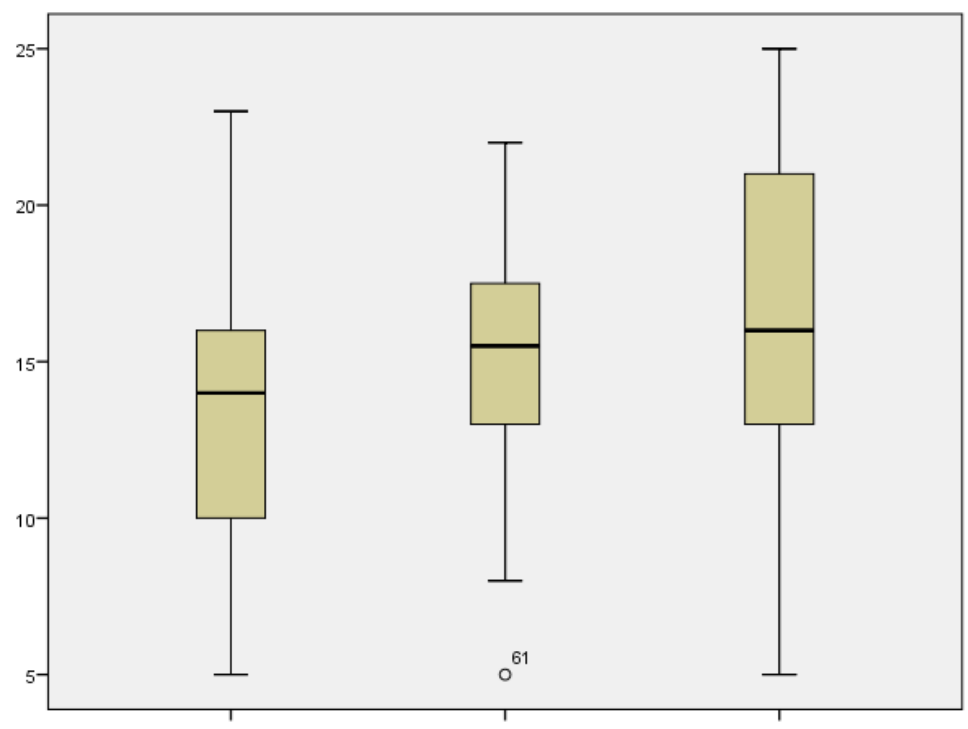

Figure 3: Boxplot diagram of the variable Collaboration versus Efficiency of technology transfer (1.Inefficient transfer, 2.Neutral transfer efficiency, 3.Efficient Transfer)

The empirical research shows that the efficient technology transfer has the strongest influence on the efficiency of $R \& D$ organisations, results in the organisations, and their collaboration, but also on all other elements of integrated strategic management concept which are presented in this research. The empirical research presented in this paper has proved previously determined research hypothesis, that the application of integrated strategic management concept in research and development organisations enables the efficient transfer of knowledge and technology from research organizations to the economy.

\section{CONCLUSION}

Historically, any form of technology transfer has generally been influenced by the economic developments of the period. Differences between types of technology transfer could be clearly understood if the human and technological developments are taken into account; goods (equipment and products) and knowledge (public information and knowhow) are considered at the same time. Usually, in the process of technology transfer, there is a movement of human resources between suppliers and recipients of technology, in both directions, while the path of goods and knowledge is one-way, from suppliers to recipients of technology (Uchida, 1990).
Starting from the quite certain findings that the effective applying of scientific research work is an important factor of economic growth, it is necessary to find a way to maximize research potential. The main problem is that slow, inefficient transfer of technology is one of the crucial limiting factors of current economic and technological development in Serbia. One way to overcome this problem and encourage technology transfer is the application of an integrated strategic management concept in research organisations that would encourage technology transfer. The main recommendation for the management of $R \& D$ institutions is the recognition of technology transfer as an important project result. In order to improve the utilization of technology transfer as a project output, there is a need for a systematic approach to the strategic management of R\&D institutions.

Based on the results of the empirical research presented in this paper, it can be clearly seen that the more efficient the technology transfer leads to better results in an organisation. Presented empirical research shows that efficient technology transfer has the biggest influence on the efficiency of $R \& D$ organizations, their results, and collaboration:

- the more efficient technology transfer, higher the efficiency of scientific research. 
- the more efficient technology transfer, better the organisational results.

- the more efficient technology transfer, better the cooperation in research and development activities.

The systematic approach enables, among other things, establishing cooperation with all stakeholders outside the organisation. Insufficient technology transfer has been identified as a weak point in $R \& D$ organizations in Serbia in the previous period and accordingly, appropriate infrastructure bodies have emerged to encourage technology transfers (technology transfer centres). Transfer technologies have an undeniable significance for organisation and more broadly, exploit the ability of the economy to generate greater economic growth.

Low levels of R\&D activities have a negative impact on levels of demand and funding for new products and services from the academic sector. There is almost impossible that universities develop and transfer new technologies if companies, governments, and investors are not seeking to finance and acquire them. The main goal of the strategic management in $R \& D$ organisations is to effectively and efficiently manage the R\&D process, which contributes to utilization of the research results and reducing costs on that basis, as well as increasing the basic knowledge base.

Bearing in mind the specific features of research and development work, effective strategic management in research organisations provides benefits not only to the management of the organisation but also to decision-makers at the national level by maximizing the quality of policy coordination and budget planning and control through the efficient allocation of the available resources.

\section{ACKNOWLEDGEMENTS}

The paper is a result of research within Projects: No. 179081 - Researching contemporary tendencies of strategic management- using specialized management disciplines in function of competitiveness of Serbian economy and No. 47005- Research and Development of platform for scientific decision support as well as management for scientific and technological development in Serbia, financed by the Ministry of Education, Science and Technological Development of the Republic of Serbia.

\section{REFERENCES}

Arnold, E., Barker, K., \& Slipersæter, S. (2010). Research Institutes in the ERA, Retrieved May 31, 2016, http://ec.europa.eu/research/era/index_en. htm.

Chanaron, J. J., \& Grange, T. (2006). Towards a Re-Definition of Technology Management. The 3rd IEEE International Conference on Management Innovation and Technology, Singapore, Indonesia.

Dabić, M. (2002). Technological Management: Expanding the Perspective for Croatia, dostupno:http://citeseerx.ist.psu.edu/view doc/download?doi=10.1.1.197.594\&rep= rep1\&type $=$ pdf

Jafee, A. (1984). Market Demand, Technological Opportunity and Research Spillovers on R\&D Intensity and Productivity Growth, NBER Working Paper No. 1432.

Milošević, N., Dobrota, M., \& Barjaktarević Rakočević, S. (2018). Exploring the impact of intellectual capital components on project performance, European Project Management Journal, 8(2), 43-51.

Murayama, K., Nirei, M., \& Shimizu, H. (2015). Management of science, serendipity, and research performance: Evidence from a survey of scientists in Japan and the U.S., Research Policy, 44(4), 862-873.

Mosurović Ružičić, M., Semenčenko D., \& Kutlača, Đ. (2015). Innovation Infrastructure for Technology Transfer and Diffusion in Serbia, Marketing Volume, 46(1), 36-46.

Obradović, V., Mosurović Ružičić, M., \& M, Dobrota, M. (2019). Gender equality in strategic management of the projects in $R \& D$ organizations in Serbia, Proceedings of the 5th IPMA SENET Project Management Conference, Challenges of Growing Economies, Belgrade, Serbia, 108, 198-202. 
OECD. (2015). Frascati Manual 2015: Guidelines for Collecting and Reporting Data on Research and Experimental Development, The Measurement of Scientific, Technological and Innovation Activities, OECD Publishing, Paris. doi: http://dx.doi.org/10.1787/978926423901 2-en

OECD. (2011). Public Research Institutions: Mapping Sector Trends, OECD Publishing. doi: http://dx.doi.org/10.1787/978926411950 $\underline{5-e n}$

Racine, J. L., Goldberg, I., Goddard, J. G., Kuriakose, S., \& Kapil, N. (2009). Restructuring of Research and Development Institutes in Europe and Central Asia, (draft), The World Bank, Private and Financial Sector Development Department.

Radošević, S. (2018). Fostering innovation in less-developed and low institutional capacity regions: Challenges and opportunities, Background paper for an OECD/EC Workshop on 22 June 2018 within the workshop series "Broadening innovation policy: New insights for regions and cities", Paris.

Robins, S. (2005). Menadžment. SP print, Novi Sad.

Uchida, H. (1990). Technology Transfer: Chapter 3, in The Era of Industrialisation, Eds Shunsaku Nishikawa and Takeji Abe, A History of the Japanese Economy, 4, Iwanami Shoten.

Suter, F. D., \& Strauss, P. B. (2007). Technology transfer - when, why, issues and advantages, Proceedings of PACO7 Albuquerque, New Mexico, USA.

Svarc, J., \& Dabic, M. (2019). The Croatian path from socialism to European membership through the lens of technology transfer policies, The Journal of Technology Transfer, 44(5), https://doi.org/10.1007/s10961-01909732-1

Wahab, A. S., Che Rose, R., \& Osman, I. W. S. (2012). Defining the Concepts of Technology and Technology Transfer: A Literature Analysis, International Business Research, 5(1). doi:10.5539/ibr.v5n1p61. 